\title{
Comparative study of the hyperbaric hyperoxygenation in ischemic colonic loops in rats $^{1}$
}

\author{
Estudo comparativo da hiperoxigenação hiperbárica em \\ alças cólicas isquêmicas em ratos
}

\author{
Antonio Angelo Rocha²; Cláudio Sadi Rodrigues Coy ${ }^{3}$; Juvenal Ricardo Navarro Góes ${ }^{4}$; Maria de Lourdes Setsuko \\ Ayrizono $^{5}$; Feng Chung Wu ${ }^{6}$ João José Fagundes ${ }^{3}$ \\ 1. Study performed at the Coloproctology Service at the Surgical Techniques Laboratory from Medicine and Experimental Surgery Center \\ - University of Campinas - UNICAMP, Brazil. \\ 2. Fellow PhD degree, Assistant Professor, Department of Surgery, Coloproctology Service, Faculty of Medical Sciences, UNICAMP, \\ Brazil. \\ 3. Associate Professor, Department of Surgery, Coloproctology Service, Faculty of Medical Sciences, UNICAMP, Brazil. \\ 4. PhD, Associate Professor of the Department of Surgery, Chief Department of Surgery, Chief of the Coloproctology Service, Faculty of \\ Medical Sciences, UNICAMP, Brazil. \\ 5. Fellow PhD degree, Department of Surgery, Coloproctology Service, Faculty of Medical Sciences, UNICAMP, Brazil \\ 6. PhD, Research Assistant Professor of the Department of Surgery - Coloproctology Service, Faculty of Medical Sciences, UNICAMP, \\ Brazil
}

\begin{abstract}
Purpose: To analyze and to evaluate the effect of the hyperbaric hyperoxygenation in the mechanical resistance of ischemic colon of rats. Methods: Eighty rats, distributed in four groups of 20 animals in each one, were used. In group 1 (G1), the control group, ischemia was not caused. Group 2 was submitted to the lesser degree of ischemia. Group 3 was submitted to the intermediate degree of ischemia. In group 4, a bigger degree of intestinal ischemia was provoked. Each group was divided in two sub-groups of ten animals each: with hyperbaric chamber (CC) and without hyperbaric chamber (SC). The animals of the four CC subgroups were placed in an experimental hyperbaric chamber in order to inhale oxygen at 100\%, at two Absolute Atmospheres, for 120 minutes, for a four-day consecutive period. The animals of the four SC subgroups were kept in environment air during the five days of the experiment. All animals have been submitted to the mechanical study of the intestinal loop by the pressure test of the rupture by liquid distension. The euthanasia occurred in the fifth post-operative day. Results: Considering the ischemia factor, the four groups were different among them $(p=0.0001)$. There was no statistical difference between subgroups CC and SC $(p=0.3461)$. Conclusion: The hyperbaric oxygen-therapy did not present improvement on the induced ischemia in rats upright colic loop.
\end{abstract}

Key words: Ischemia. Colon. Hyperbaric oxygenation. Rats

\section{RESUMO}

Objetivo: Analisar e avaliar os efeitos da hiperoxigenação hiperbárica na resistência mecânica do cólon isquêmico de ratos. Métodos: Foram utilizados 80 ratos distribuídos em quatro grupos de 20 animais. No grupo 1, grupo controle, não se provocou isquemia. $\mathrm{O}$ grupo 2 foi submetido ao grau menor de isquemia. O grupo 3 foi submetido ao grau intermediário de isquemia. No grupo 4, provocou-se grau maior de isquemia intestinal. Cada grupo foi dividido em dois subgrupos de dez animais cada: com câmara hiperbárica (CC) e sem câmara hiperbárica (SC). Os animais dos quatro subgrupos CC foram colocados em uma câmara hiperbárica experimental para inalarem oxigênio a 100\%, a duas atmosferas absolutas, durante 120 minutos, por quatro dias consecutivos. Os animais dos quatro subgrupos SC foram mantidos somente em ar ambiente. Todos animais foram submetidos ao estudo mecânico da alça intestinal pelo teste de pressão de ruptura pela distensão por líquido. A eutanásia ocorreu no quinto dia pós-operatório. Resultados: Os quatro grupos são diferentes entre si considerando o fator isquemia $(p=0.0001)$. Não houve diferença estatística entre os subgrupos CC e SC ( $p=0.3461)$. Conclusão: A oxigenoterapia hiperbárica não apresentou melhora sobre a isquemia induzida em alça cólica íntegra de ratos.

Descritores: Isquemia. Cólon. Oxigenação hiperbárica. Ratos. 


\section{Introduction}

Intestinal healing is a complex subject. Poor healing can lead to expressive morbidity and mortality indexes ${ }^{(1)}$. Understanding intestinal response to adverse situations is a widely researched issue. For this reason, studies to understand intestinal response to adverse situations are common and current.

Almost all studies are related to anastomosis healing. In addition to the surgical technique and suture materials, some factors interfere with anastomosis quality. Among them are the effects of substances on healing anastomosis phases, such as antibiotics ${ }^{(2)}$, hormonal and non-hormonal anti-inflamatories ${ }^{(3,4,5)}$, antioxidants ${ }^{(6)}$, anti-neoplasics ${ }^{(7)}$, imuno-suppressor drugs ${ }^{(8)}$, and hormones ${ }^{(9)}$. Other factors that interfere with intestinal anastomosis are also being studied, such as shock ${ }^{(10,11)}$, peritonite ${ }^{(12,13,14)}$, and adherences action ${ }^{(15,16)}$. In addition to these factors, local secondary hypoxy related to a decrease in sanguineous perfusion is an important agent that can cause anastamotic complications $(10,17,18,19,20,21,22,23)$.

Ischemic colopathy is a special situation. Since studies on the ischemic intestine include anastomosis, it is difficult to extrapolate the results. It is not clear if the therapeutic models employed for ischemic anastomosis would be valid for the ischemic colon without being sectioned. Such interest goes back to colon ischemia and its eventual treatment by hyperbaric oxygen. Hyperbaric hiperoxya (HBO) consists of inhalation of $100 \%$ oxygen at a pressure above atmospheric pressure and presents a definite role in the treatment of several diseases ${ }^{(24)}$. In hyperbaric medicine, environmental pressure values are referred to as absolute atmospheres (atm abs) or ATA. At sea level, the pressure is defined as $1 \mathrm{ATA}=1 \mathrm{~atm}$ abs $=760$ millimeters of mercury. Some authors experimentally report an improvement in intestinal anastomosis healing with its use in the presence or absence of ischemia ${ }^{(22,23)}$. However, the effects of hyperbaric hiperoxya on intestinal ischemia on the upright colon loop without anastomosis are still controversial.

In this study, the effects of hyperbaric oxygen-therapy on the upright colon loop were analyzed, considering three different degrees of induced ischemia. A mechanical study of the intestinal loop was proposed through a pressure test through rupture by liquid distension in order to determine the quality of intestinal healing.

\section{Methods}

This work was approved by the Animal Experimentation Ethics Commission (CEEA-IB-UNICAMP), according to Ethical Principles adopted by the Brazilian College of Animal Experimentation (COBEA) - Protocol \# 588-1. Eighty male rats were used, Wistar-CEMIB/ UNICAMP, with weights varying from 300 to 350 grams. These animals were raised under similar environmental and feeding conditions. The animals used were kept in specific cages with five rats. The light/dark cycle was characterized by artificial lightning for a period of 12 hours a day, and temperature and humidity were equivalent to the general environment. The animals had free access to food and water throughout the experiment. There was no fasting before the surgical procedure. These 80 rats were distributed in 4 groups and each group was subdivided into 2 subgroups containing 10 animals (Figure 1). The anesthesia was intravenous (tail vein) with a $3 \%$ sodium pentobarbital solution diluted in physiological solution $(5 \mathrm{mg} / \mathrm{ml})$; a 30 $\mathrm{mg} / \mathrm{kg}$ dose was applied. After xifopubic medium laparotomy and exposure of colic veins, ischemia was induced with a 4.0 polypropylene thread in the following manner: Group 1 (G1) - control group - group without ischemia (Figure 2); group 2 (G2) was submitted to a lesser degree of ischemia with linkage of the inferior mesenteric artery trunk and marginal arcade four centimeters above the peritoneal reflection (Figure 3).

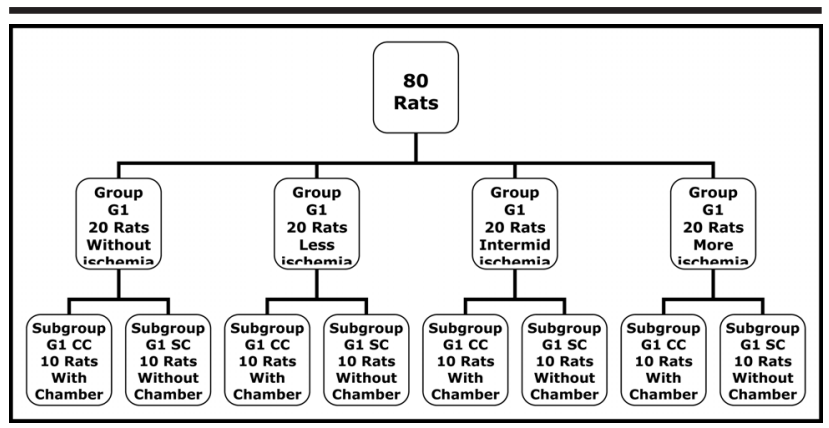

FIGURE 1 - Experimental fluxogram. Groups and subgroups distribution and characteristics.

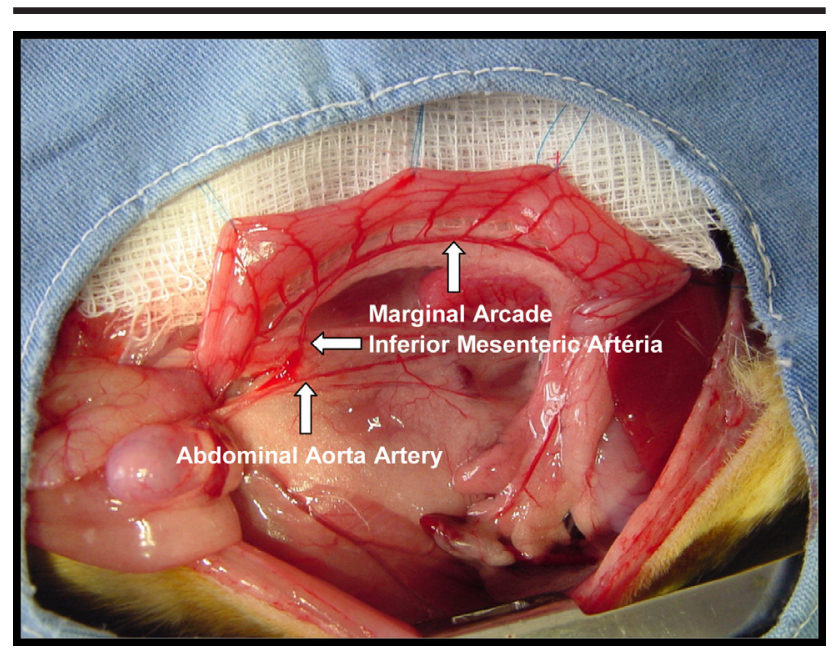

FIGURE 2 - Animal from Group 1

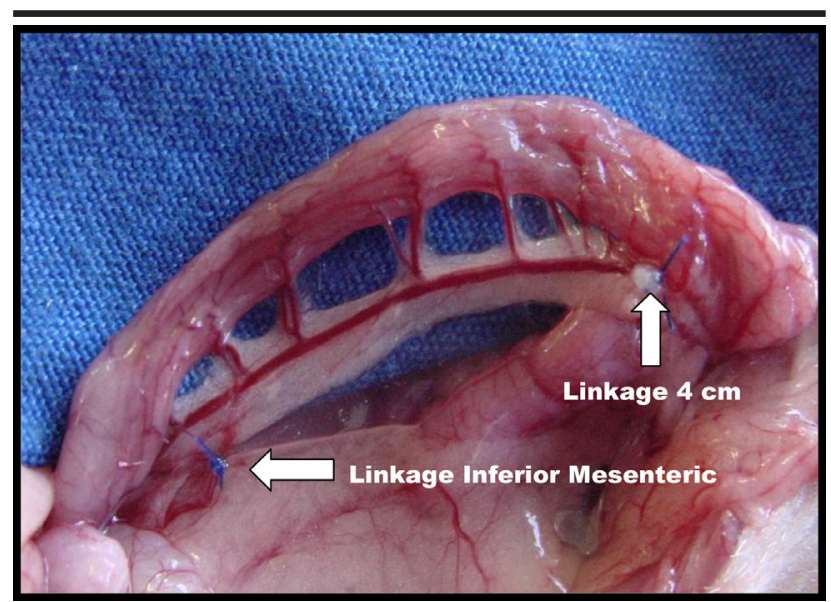

FIGURE 3 - Animal from Group 2 
Group 3 (G3) was submitted to an intermediary ischemia level with linkage of the inferior mesenteric artery trunk and marginal arcade four centimeters above the peritoneal reflection and at the peritoneal reflection level (Figure 4). In Group 4 (G4) ischemia was amplified by linkage of the inferior mesenteric artery trunk, linkage of the marginal arcade to the peritoneal reflection level and trunk linkage of the medium colon veins (Figure 5).Right after the operations were concluded, each group of twenty animals was subdivided into two subgroups of ten animals: subgroup $\mathrm{CC}$ and SC. The animals of group $\mathrm{CC}$ were placed in a hyperbaric experimental chamber to inhale oxygen at $100 \%$, 2 ATA, for 120 minutes. Each session was repeated daily, at the same time, for four consecutive days. In between sessions, the animals breathed environmental air and had free access to food and water. The rats from the subgroups $\mathrm{SC}$ remained in cages with five animals and breathed environmental air during the 5-day period of the experiment. Euthanasia occurred on the fourth post-operative day (fifth experimental day) with a lethal dose of $3 \%$ sodium pentothal in the tail vein. The abdominal cavity was opened and a five centimeter colon segment, measured from the peritoneal reflection was removed and submitted to intraluminar cleaning. The specimens were immersed in a solution containing papaverine chloridate and saline solution $\left(250 \mathrm{mg} /\right.$ litro) at $37^{\circ} \mathrm{C}$, for a 30 minute period.

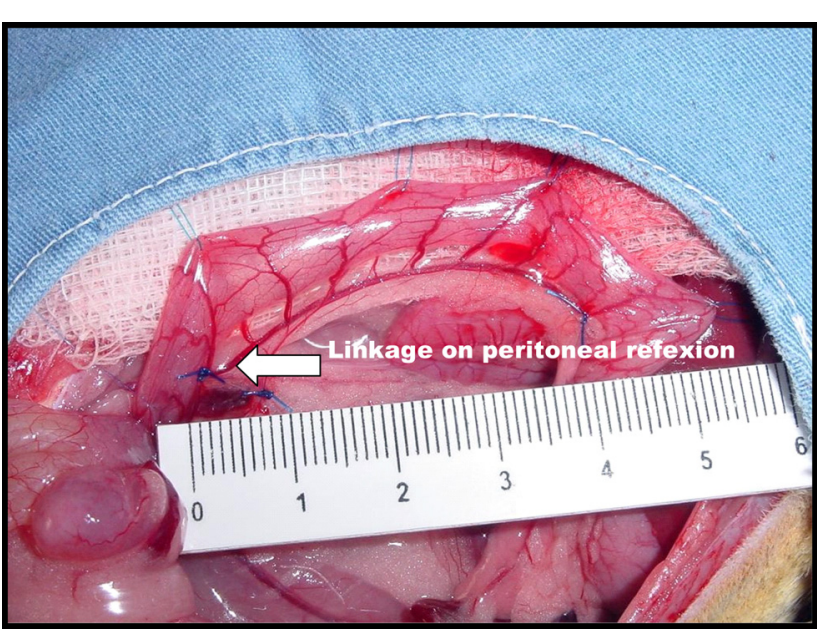

FIGURE 4 - Animal from Group 3

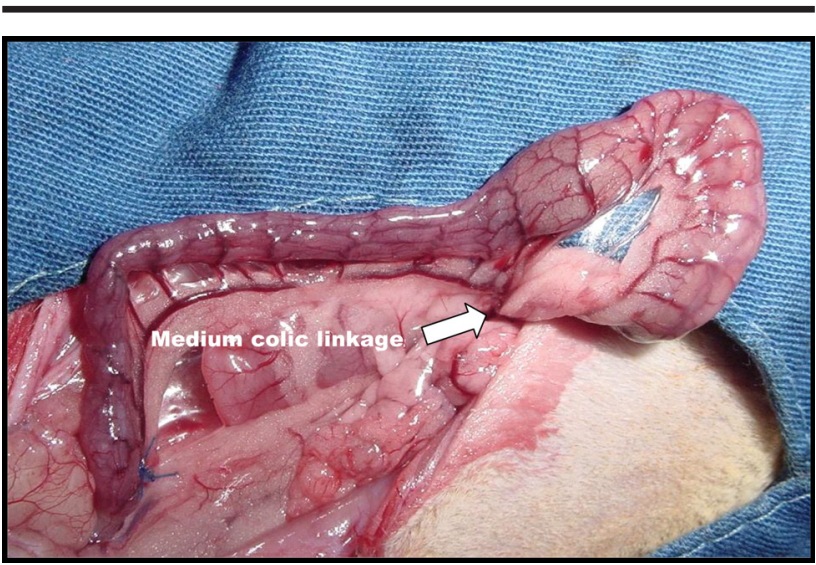

FIGURE 5 - Animal from Group 4

\section{Intestinal loop mechanical study}

All specimens were submitted to the Pressure of Rupture by Liquid Distension resistance test (PRDL). The PRDL test was defined as the intraluminar pressure necessary to promote solution overflow through the loop wall, by continuous infusion on isolated loop extremities. The specimen was coupled to a three-way tap $(N I P R O \AA)$ installed on an infusion pump syringe (B. BRAUN-871.012) and on the support system. The segment to be infused with physiological solution was reduced to two centimeters (Figure 6). A polyethylene catheter connected the system to a polygraph (GOULD RS 3800), forming a communication vase system. This situation was considered as zero initial parameter and the PRDL study was initiated by infusion of physiological solution at a constant speed of $2 \mathrm{ml} /$ minutes. The infusion was concluded after a pressure meter fall, which corresponded to the loop rupture. The pressure was recorded by a polygraph as millimeters of mercury (Figure 7). Variance Analysis (ANOVA) and Tukey Test were the statistical analysis employed to evaluate the results. These were considered different when $\mathrm{p} \leq 0.05$.

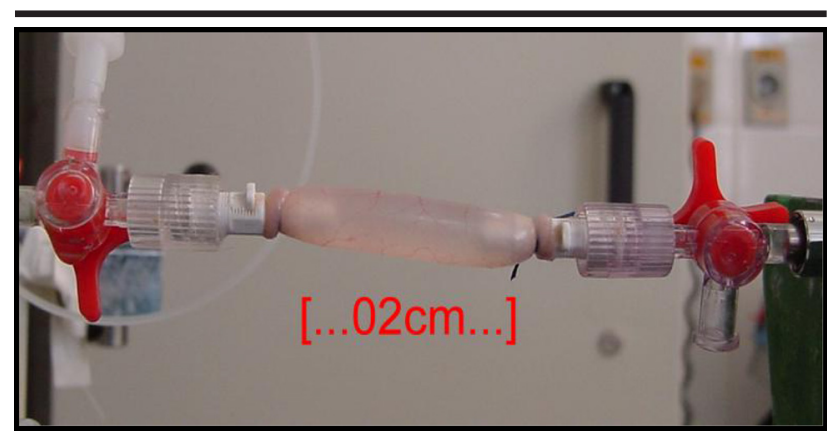

FIGURE 6 - Detail of the loop ready for the rupture test

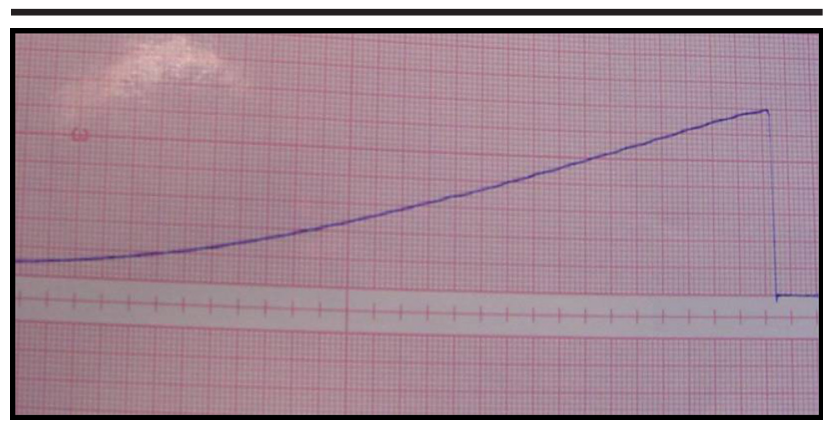

FIGURE 7 - Graphic recording showing the Pressure of Rupture by Distension. The curve is ascending and there is a sudden drop at the rupture time.

\section{Results}

The animals had good clinical evolution during the post-operative period. There was no death registered. The rupture pressure values for each rat are expressed as millimeters of mercury on Table 1 . The values for average rupture pressure by liquid distension of the four groups were compared on graphs 1 and 3 , and the values of the eight subgroups were compared on graph 2 . Analyzing the ischemia and hyperbaric chamber factors (Table 2). 
It is possible to conclude that the groups are different from one another by analyzing the variance $(p=0.0001)$. Through the Tukey test, it can be concluded that group 4 is more ischemic than group 3; group 3 does not differ from group 2; however, group 2 is more ischemic than group 1 ( $p$ $\leq 0.05)$. It can be concluded that there is no statistical difference when the hyperbaric chamber effect is analyzed $(p=0.3461)$.

TABLE 1 - Individual values for pressure of rupture by liquid distension ( $\mathrm{mmHg}$ ) on 80 animals studied.

\begin{tabular}{|c|c|c|c|c|c|c|c|c|}
\hline & \multicolumn{2}{|c|}{ GROUP 1} & \multicolumn{2}{|c|}{ GROUP 2} & \multicolumn{2}{|c|}{ GROUP 3} & \multicolumn{2}{|c|}{ GROUP 4} \\
\hline & $\begin{array}{c}\text { Subgroup } \\
\text { G1 CC }\end{array}$ & $\begin{array}{c}\text { Subgroup } \\
\text { G1 SC }\end{array}$ & $\begin{array}{c}\text { Subgroup } \\
\text { G2 CC }\end{array}$ & $\begin{array}{c}\text { Subgroup } \\
\text { G2 SC }\end{array}$ & $\begin{array}{c}\text { Subgroup } \\
\text { G3 CC }\end{array}$ & $\begin{array}{c}\text { Subgroup } \\
\text { G3 SC }\end{array}$ & $\begin{array}{c}\text { Subgroup } \\
\text { G4 CC }\end{array}$ & $\begin{array}{c}\text { Subgroup } \\
\text { G4 SC }\end{array}$ \\
\hline R1 & 248 & 200 & 180 & 220 & 184 & 224 & 160 & 170 \\
\hline $\mathbf{R} 2$ & 240 & 274 & 160 & 200 & 184 & 184 & 152 & 154 \\
\hline $\mathbf{R 3}$ & 216 & 240 & 180 & 170 & 172 & 236 & 156 & 160 \\
\hline R4 & 278 & 200 & 200 & 250 & 176 & 200 & 158 & 144 \\
\hline R5 & 200 & 230 & 210 & 232 & 156 & 184 & 148 & 130 \\
\hline R6 & 176 & 200 & 180 & 208 & 160 & 176 & 132 & 144 \\
\hline R7 & 176 & 274 & 170 & 160 & 144 & 168 & 132 & 160 \\
\hline R8 & 200 & 176 & 200 & 170 & 160 & 116 & 172 & 140 \\
\hline R9 & 200 & 200 & 180 & 200 & 150 & 190 & 178 & 148 \\
\hline R10 & 280 & 232 & 190 & 140 & 184 & 152 & 122 & 140 \\
\hline
\end{tabular}

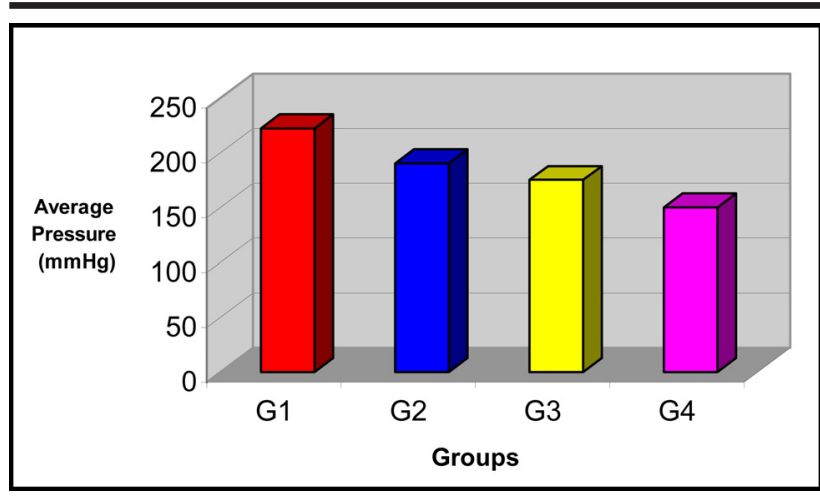

GRAPH 1 - Graphic distribution of the values for average rupture pressure by liquid distension $(\mathrm{mmHg})$ for the four groups.

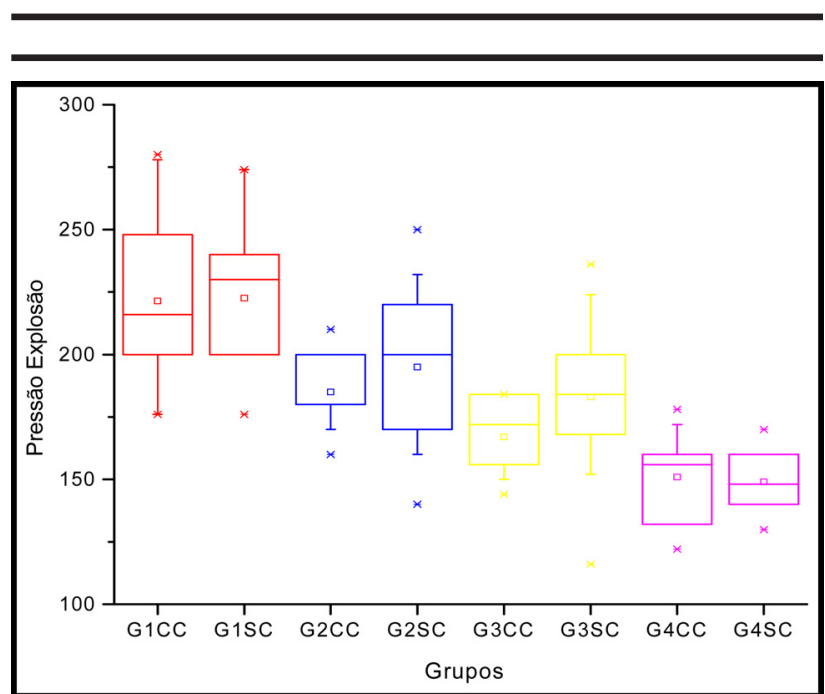

GRAPH 3 - "Box-Plot" of the rupture pressure by liquid distension $(\mathrm{mmHg})$ by groups and subgroups.

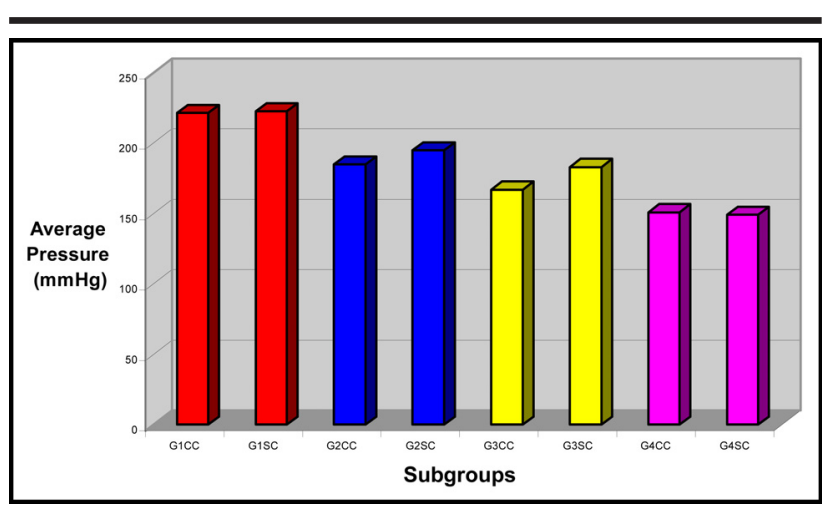

GRAPH 2 - Graphic distribution of the values for average rupture pressure by liquid distension $(\mathrm{mmHg})$ for the eight subgroups.

Comparison of groups

\section{Tukey test for rupture pressure}

Averages with the same letter are not statistically different

Group
G1
G2
G3
G4

$\mathbf{N}$
20
20
20
20

\begin{tabular}{cc} 
Average & \\
222 & $\mathrm{~A}$ \\
190 & $\mathrm{~B}$ \\
175 & $\mathrm{~B}$ \\
150 & $\mathrm{C}$ \\
\hline
\end{tabular}


TABLE 2 - Results of the variance analysis (on Ranks) for the variable rupture pressure by liquid distension.

\begin{tabular}{lrrrrr}
\hline Variation source & g.l. & $\begin{array}{c}\text { Square } \\
\text { Sum }\end{array}$ & $\begin{array}{c}\text { Average } \\
\text { Square }\end{array}$ & F & P-value \\
\hline Group & 3 & 23101,77 & 7700,59 & 29,95 & $\mathbf{0 , 0 0 0 1}$ \\
Chamber & 1 & 231,20 & 231,20 & 0,90 & 0,3461 \\
Group*Chamber & 3 & 606,67 & 202,22 & 0,79 & 0,5053 \\
\hline
\end{tabular}

\section{Discussion}

A decrease of sanguineous perfusion on a surgical wound is one of the most important causes of post operative complications. This event, when not reversed, can compromise the oxygen available to the healing tissue, altering its reparation physiology ${ }^{(25)}$. The correction of hypoxemia through administration of supplementary oxygen, particularly in hyperbaric conditions, can be therapeutically efficient in healing wounds under these conditions ${ }^{(26)}$. Hyperbaric oxygen-therapy, when employed on the intestine with induced ischemia, refers to healing of intestinal anastomosis in most of the literature work. In those studies in which hyperbaric oxygen-therapy was employed to treat ischemic colic anastomosis, this technique was efficient at minimizing hypoxia damage ${ }^{(22,23)}$. Dockendorf et al. (27) provoked ischemia in rat's jejunum without anastomosis. They observed that there was no statistical difference between the groups regarding complications induced by ischemia. Therefore, these authors concluded that hyperbaric oxygen-therapy has a limited value on treating acute ischemia in the small intestine. The objective of this work was to analyze the effect of hyperbaric oxygentherapy on three progressive degrees of acute ischemia provoked in rats' left intact colon loop, without the use of sectioning or anastomosis. The presence of loose adherences over the ischemic colon in some animals was observed in the group with more intense ischemia, as well as areas of apparent ischemia of the colon wall, but without macroscopic signs of gangrene. These alterations suggested the gravity of ischemia installed by the experimental model and therefore the proposed objective was achieved. Mortality was not observed in the groups, even though the ischemia induced was visible. The measurement of the mechanical resistance for the loops tested also showed that they became acutely ischemic. In order to perform these evaluations, the biomechanical test of Pressure of Rupture by Liquid Distension was chosen, for the purpose of determining the quality of intestinal healing through its mechanical resistance. The animals from the control group (G1) were not submitted to ischemia. The animals from group 2 (G2) were submitted to a lesser degree of ischemia. The average rupture pressure for G1 was statistically higher than the average for $\mathrm{G} 2$, which proves the ischemia induced in group G2. The animals from group 3 (G3) were submitted to an intermediary degree of ischemia, higher than G2 and smaller than G4. There was no statistical difference between $\mathrm{G} 2$ and $\mathrm{G} 3$ regarding the rupture pressure. A higher degree of ischemia was induced on animals from group 4 than animals from G2 and G3. However, the average rupture pressure for G4 was statistically smaller than G3, which proves an increase of ischemia. The four groups were divided into two subgroups: CC (with chamber) and SC (without chamber). There was no statistical difference between the subgroups. Therapy with hyperbaric chamber was not able to improve the effects of ischemia in colon loops without anastomosis. Most likely, the colon sectioning that causes anastomosis completely interrupts the sanguineous offer by the viscera wall. Therefore the integrity of intraparietal veins must represent a factor of sanguineous demand and protection to the ischemic territory. A research line is then opened to obtain more intense ischemia and higher lethality indexes. Perhaps hyperbaric hyperoxya can influence the results under extreme ischemia conditions.

\section{Conclusion}

Advantages were not observed by employing hyperbaric hyperoxygenation in induced colic ischemia.

\section{Acknowledgement}

We thank the Biologists from the UNICAMP Experimental Surgery Nucleus, Ana Cristina de Moraes and William Adalberto Silva; and also thank Prof. Virgínio Cândido Tosta de Souza (Titular Professor of the Surgery Department and Chief of the Proctology Course of the Vale do Sapucaí University - Pouso Alegre - MG) for his help with this paper.

\section{References}

1. Fagundes JJ. - Estudo comparativo da cicatrização de anastomoses cólicas realizadas com auxílio do bisturi laser de dióxido de carbono: trabalho experimental em cães [Tese - Doutorado]. Faculdade de Ciências Médicas da UNICAMP; 1990.

2. Cohen SR, Cornell CN, Collins MH, Sell JE, Blanc WA, Altman RP. Healing of ischemic colonic anastomoses in the rat: role of antibiotic preparation. Surgery. 1985; 97(4): 443-6.

3. Martins Júnior A, Guimarães AS, Ferreira AL. Efeito dos corticosteróides na cicatrização de anastomoses intestinais. Acta Cir Bras. 1992; 7: 28-30.

4. Furst MB, Stromberg BV, Blatchford GJ, Christensen MA, Thorson AG. Colonic anastomoses: bursting strength after corticosteroid treatment. Dis Colon Rectum. 1994; 37: 12-5.

5. Minossi JG. Ação do diclofenaco de sódio na cicatrização de anastomoses realizadas no íleo terminal e no cólon distal de ratos. Estudo da força de ruptura, hidroxiprolina tecidual e exame histológico [Tese Doutorado]. Universidade Estadual Paulista; 1995.

6. Garcia GG, Criado FJG, Persona MAB, Alonso AG. Healing of colonic ischemic anastomoses in the rat: role of superoxide radicals. Dis Colon Rectum. 1998; 41: 892-5.

7. Yazdi PG, Miedema BW, Humphrey L. Immediate postoperative 5-FU does not decrease colonic anastomotic strength. J Surg Oncol. 1998; 69:125-7. 
8. Mantovani M, Leonardi LS, Alcântara FG. Evolução da cicatrização em anastomoses do intestino grosso de cães em condições de normalidade e sob ação de drogas imunossupressoras. Estudo comparativo em cães. Rev Paul Med, 1979; 94: 118-26.

9. Yarimkaya A, Apaydin B, Unal E, Karabicak I, Aydogan F, Uslu E, Erginoz E, Artis T, Eyuboglu E. Effects of recombinant human growth hormone and nadrolone phenylpropionate on the healing of ischemic colon anastomosis in rats. Dis Colon Rectum. 2003; 46: 1690-7.

10. Greca FH, Biondo-Simoes MLP, Paula JB, Noronha L, Cunha LSF, Baggio PV, Bittencourt FO. Correlação entre o fluxo sangüíneo intestinal e a cicatrização de anastomoses colônicas: estudo experimental em cães. Acta Cir Bras. 2000;15: 88-94.

11. Brito MVH, Koh IHJ, Lamarão LG, Damous SHB. Efeito do choque hipovolêmico na anastomose do intestino delgado de ratos. Arq Gastroenterol. 2001; 38:116-24.

12. Naresse LE. Efeito da peritonite fecal na cicatrização do cólon distal no rato. Avaliação anatomo-patológica, estudo da força de ruptura e da hidroxiprolina tecidual [Tese Doutorado]. Universidade Estadual Paulista; 1990.

13. Biondo-Simões MLP, Greca FH, Bryk Junior A, Komatsu MCG, Bittencourt FO, Greca LM. Influência da peritonite sobre a síntese de colágeno em anastomoses do cólon distal: estudo experimental em ratos. Acta Cir Bras. 2000; 15: 69-73.

14. Fraga GP. Análise de fatores de risco no tratamento de lesões de ceco com sutura primária em ratos [Dissertação - Mestrado]. Faculdade de Ciências Médicas da UNICAMP; 2001.

15. Decherney AH, Dizerega GS. Clinical problem of intraperitoneal postsurgical adhesion formation following general surgery and the use adhesion prevention barriers. Surg Clin NAm. 1997; 77: 671-89.

16. Wu FC, Ayrizono MLS, Fagundes JJ, Coy CSR, Góes JRN, Leonardi LS. Estudos biomecânicos da ação de aderências sobre anastomose cólica. Trabalho experimental em ratos. Acta Cir Bras. 2003; 18: 216-23.

17. Schrok TR, Deveney CH, Dunphy JE. Factors contributing to leakage of colonic anastomosis. Ann Surg. 1973; 127: 513-8.

18. Tagart RE. Colorectal anastomosis: factors influencing success. J R Soc Med. 1981; 74: 111-8.

19. Khoury GA, Waxmann BP. Large bowell anastomoses. I. The healing process and suture anastomoses. A review. Br J Surg. 1983; 70: 61-3.

20. Foster ME, Laycock JR, Silver IA. Hypovolaemia and healing in colonic anastomosis. Br J Surg. 1985; 72: 831.

21. Van der Ham AC, Kort WJ, Weijma IM. Healing of ischemic colonic anastomosis: fibrin sealant does not improve wound healing. Dis Colon Rectum. 1992; 35 : 884-90.

22. Hamzaoglu I, Karahasanoglu T, Aydin S, Sahin DA, Carkman S, Sariyar M, Alemdaroglu K. The effects of hyperbaric oxygen on normal and ischemic colon anastomoses. Am J Surg. 1998; 176: 458-61.

23. Wu FC. Estudo dos efeitos de diferentes concentrações de oxigênio e da hiperoxigenação hiperbárica sobre anastomose cólica comprometida ou não pela isquemia: trabalho experimental em ratos [Tese - Doutorado]. Faculdade de Ciências Médicas da UNICAMP; 2003.

24. Tibbles PM, Edelsberg JS. Hyperbaric-oxygen therapy. N Engl J Med. 1996; 334: 1642-8.

25. Iazzetti PE. Hiperoxigenação hiperbárica. In: Terzi RGG. Equilíbrio ácido-básico e transporte de oxigênio. São Paulo: Manole; 1992. p.180-204.

26. Gordillo GM, Sen CK. Revisiting the essential role of oxygen in wound healing. Am J Surg. 2003; 186(3): 259-63.

27. Dockendorf BL, Frazee RC, Peterson WG, Myers D. Treatment of acute intestinal ischemia with hyperbaric oxygen. South Med J. 1993; 86: 518-22.

\section{Correspondence}

Antonio Angelo Rocha

Praça Francisco Escobar, 201 - Sala 36

Centro - Poços de Caldas - MG 37701-000

angelorocha@terra.com.br
Received: October 22, 2004

Revised: November 30, 2004

Approved: December 19, 2004

Conflict of interest: none

Financing source: none

How to cite this paper: Rocha AA, Coy CSR, Góes JRN, Ayrizono MLS, Wu FC, Fagundes JJ. Comparative study of the hyperbaric hyperoxygenation in ischemic colonic loops in rats. Acta Cir Bras [serial on the Internet] 2005 Mar-Abr; 20(2). Available on URL: http://www.scielo.br/acb 